\title{
THE FIRST REPORT OF TITYUS (SCORPIONES: BUTHIDAE) IN ANZOÁTEGUI STATE, VENEZUELA. A NEW SPECIES
}

\section{QUIROGA M. ${ }^{1}$, DE SOUSA L. ${ }^{2,3}$, PARRILLA-ÁLVAREZ P. ${ }^{1}$, MANZANILLA J. ${ }^{4}$}

${ }^{1}$ Laboratorio de Alacranología, Escuela de Medicina, Universidad de Oriente, Núcleo de Bolívar, Ciudad Bolívar, Venezuela; ${ }^{2}$ Grupo de Biomedicina Aplicada (GBA), Centro de Investigaciones en Ciencias de la Salud (CICS), Escuela de Medicina, Universidad de Oriente, Núcleo de Anzoátegui, Puerto La Cruz, Venezuela; ${ }^{3}$ Postgrado de Biología Aplicada, Escuela de Ciencias, Universidad de Oriente, Núcleo de Sucre, Cumaná, Venezuela; ${ }^{4}$ Instituto de Zoología Agrícola, Facultad de Agronomía, Universidad Central de Venezuela, Maracay, Venezuela.

ABSTRACT. Tityus gonzalespongai $\mathrm{n}$. $\mathrm{sp}$. is a species endemic to the high mountains of Anzoátegui State, Venezuela. It is found between 1,600 and 2,200 m in "La Laguna" mountain. Its habitat includes the area of "Bosque Húmedo Montano Bajo" with the type of vegetation of "Bosque Ombrófilo Montano Siempreverde" ("Bosques Nublados Costeros" that includes the "Subpáramos Arbustivos"). It is distinguished from other Tityus species ( $T$. caripitensis, T. monaguensis, and T. nororientalis) by the following characteristics: 1- the disposition of the trichobothria in the pedipalps; 2- ventral keels of the caudal segments of the metasoma (segment II, double and parallel in the proximal two thirds, then convergent and finally divergent in the base; segments III and IV, double and parallel in the basal third, then convergent in a single keel that divides in the base); 3- the number of lines of denticles of the movable finger of the right pedipalp $($ male $=14 ;$ female $=14) ; 4$ - pectineous teeth $($ right $/$ left: male $=15 / 15:$ female $=16 / 15)$; 5- color: movable and fixed fingers dark brown; prosoma and metasoma, ochre; caudal segment IV, slightly darker than the previous ones; $\mathrm{V}$ and the telson, dark brown. $T$. gonzalespongai belongs to the "androcottoides" group and presents a marked sexual dimorphism. It is the first species of the Tityus genus described and reported in Anzoátegui State, expanding this taxa distribution in Venezuela.

KEY WORDS: scorpion, Buthidae, Tityus gonzalespongai, new species, Turimiquire, Anzoátegui, Venezuela.

CORRESPONDENCE TO:

L. DE SOUSA, Apartado Postal 4774, Puerto La Cruz 6023, Estado Anzoátegui, Venezuela. Email: leonardodesousa@yahoo.com 
M. Quiroga et al. THE FIRST REPORT OF TITYUS (SCORPIONES: BUTHIDAE) IN ANZOÁTEGUI STATE, VENEZUELA. A NEW SPECIES. J. Venom. Anim. Toxins incl. Trop. Dis., 2004, 10, 1, p.11.

\section{INTRODUCTION}

There are four families of scorpions in Venezuela (Buthidae, Chactidae, Diplocentridae, Scorpionidae), which up until the year 2000 included 19 genera and 123 species (2). The Tityus genus that includes the scorpions of medical importance has at present 43 species in the whole country $(2,8,9,11)$. González-Sponga (6) has grouped the species of this genus in three "artificial groups". The "discrepans" group is characterized by possessing a medial ventral keel in segments II to IV. The "nematochirus" group presents double and complete ventral keels in the caudal segments I to IV of the metasoma, and the "androcottoides" group presents double and parallel keels in caudal segment I; double and parallel until the proximal half and single in the rest of II, III, and IV segments.

Of the seven species described for the northeastern region of Venezuela, one belongs to the "discrepans" group (T. arellanoparrai) (6), one to the "nematochirus" group ( $T$. tamayoi) (6), and five to the "androcottoides" group (T. monaguensis, T. surorientalis, T. nororientalis, T. caripitensis and, T. uquirensis) $(6-8,11)$.

Scorpions of the Buthidae family were found during a field trip to the northeastern area of Anzoátegui State. A study of these specimens revealed a new species of Tityus, which is described here.

\section{MATERIALS AND METHODS}

Tityus gonzalespongai was collected in an area of high mountains in the Turimiquire massif in Anzoátegui State during field work as part of the project to characterize the endemic macroregion of scorpionism in the northeastern region of Venezuela (4).

The scorpions were captured by means of an active hunt in their natural refuges. During the day, scorpions were searched for under stones, tree barks, trash, inside decomposing trunks, and in cracks on the roadside banks. At night, an ultraviolet lamp was used to search for scorpions on the roadside banks. 
M. Quiroga et al. THE FIRST REPORT OF TITYUS (SCORPIONES: BUTHIDAE) IN ANZOÁTEGUI STATE, VENEZUELA. A NEW SPECIES. J. Venom. Anim. Toxins incl. Trop. Dis., 2004, 10, 1, p.12.

It was conformed a Type Series consisting of 10 specimens (1 male holotype, 4 male paratypes, and 5 female paratypes). The specimens are deposited in the "Colección de Escorpiones del Laboratorio de Toxinología" (“CELT”), at the School of Medicine, "Universidad de Oriente" (UDO), "Núcleo de Anzoátegui" and in the "Colección de Escorpiones del Museo del Instituto de Zoología Agrícola” (MIZA) of the Agronomy Faculty, "Universidad Central de Venezuela" (UCV).

A Morphometric Series was established (11 males and 31 females) to obtain the median according to Hodges and Lehmann and 95\% confidence limits for feature measurements to differentiate males from females of this species. Differences between medians of male and female structure were tested by the Kruskal-Wallis analysis of variance. A significance level $\mathrm{p}<0.05$ was used. For data analysis, we used the V-8.2 statistical package of Dr. Carlos Sevcik from the "Laboratorio de Neurofarmacología Celular" of the "Centro de Biofísica y Bioquímica", IVIC, Caracas.

The morphological characteristics of the specimens were evaluated with a precision stereoscopic microscope with lucid camera (Zeyss). All the drawings were made with a 160x magnification. For denomination of the trichobothria, the classic Vachon nomenclature (13) was used. For denominati on of the different structures, Stahnke nomenclature was used (12).

The metric features of the Type Series and of the Morphometric Series were measured as follows: 1. length of the carapace; 2 . length from the right lateral eye to the right median eye; 3 . distances between the median eyes; 4 . length of the right chela; 5 . width of the right chela; 6 . length of the movable finger of the right chela; 7 . length of the right tibia; 8 . length of the right femur; 9. length of the mesosoma; 10. length of the right pectin; 11. width of the caudal segments; 12. length of the caudal segments; 13. length of the telson; and 14 . overall length of the scorpion. 
M. Quiroga et al. THE FIRST REPORT OF TITYUS (SCORPIONES: BUTHIDAE) IN ANZOÁTEGUI STATE, VENEZUELA. A NEW SPECIES. J. Venom. Anim. Toxins incl. Trop. Dis., 2004, 10, 1, p.13.

\section{Tityus gonzalespongai n. sp.}

Holotype CELT-126. Adult male specimen collected by Luis Alberto Rodríguez Maracay, Ricardo Marcano, and Leonardo De Sousa on 19/7/1997 in "La Orquídea" coffee plantation (occupying an approximate area of $1 \mathrm{~km}^{2}$ ) of the "La Laguna" mountain at 1,600 meters above sea level, between $64^{\circ} 22^{\prime} 39^{\prime \prime}$ and $64^{\circ} 22^{\prime} 70^{\prime \prime} \mathrm{W}$, $10^{\circ} 00^{\prime} 44^{\prime \prime}$ and $10^{\circ} 01^{\prime} 17^{\prime \prime} \mathrm{N}$. This is $4.8 \mathrm{~km}$ far from the village "La Piedra de Mundo Nuevo", Libertador parish (towards the northeast of Anzoátegui State, near the borders of Monagas and Sucre Sates), Freites municipality, Anzoátegui State, Venezuela (Figure 1).

PARATYPes. Four adult male specimens (CELT-129: 19/7/1997, CELT-210 to 212: 10/3/1999) and five adult female specimens (CELT-106, CELT-112-113, CELT-115, and, CELT-117: 19/7/1997) all captured in the same locality by the same collectors of Holotype.

DisTRIBUTION. Found only at this location and surrounding areas between 1,600 and 2,200 meters above sea level.

HABitat. It corresponds to the life area of the "Bosque Húmedo Montano Bajo" (according to Ewel et al. (5): bh-MB) with the vegetation type of "Bosque Ombrófilo Montano Siempreverde" ("Bosques Nublados Costeros" that includes the "Subpáramos Arbustivos”) (10). Climate: Type G (“Templado de Altura Tropical”).

ETYMOLOGY. gonzalespongai is the latinization of the composite last name of Professor Manuel Ángel González-Sponga, a renowned Venezuelan scorpion expert. According to De Sousa et al. (2) 96 out of 123 species of scorpions described in Venezuela until the year 2000 were described by Professor Manuel Ángel GonzálezSponga, approximately $78 \%$ of the Venezuelan scorpiofauna.

DiAgnOSIS. Tityus gonzalespongai $\mathrm{n}$. sp. (Figures $2 \mathrm{a}, 2 \mathrm{~b}$ ) is distinguished from $T$. caripitensis, T. monaguensis, and T. nororientalis, its nearest relative, by the following characteristics: 1. total length of the male $77.64 \mathrm{~mm}$ (Holotype, CELT-126) and of the 
female $69.90 \mathrm{~mm}$ (Paratype, CELT-106); 2. the disposition of the trichobothria in the pedipalps; 3 . ventral keels of the caudal segments of the metasoma: double and parallel in the proximal two thirds of segment II, then convergent and finally divergent in the base; double and parallel in the basal third of segments III and IV , then convergent in a unique keel that divides in the base; 4 . the number of lines of denticles of the movable finger of the right pedipalp (male $=14$; female $=14$ ); 5 . pectineous teeth (right/left): male $=15 / 15$; female $=16 / 15 ; 6$. color: male, dark brown; movable and fixed fingers, dark brown; prosoma and metasoma, ochre; caudal segment IV, slightly darker than the previous ones; segment $\mathrm{V}$ and the telson, dark brown. Female, dark brown; fixed and movable fingers, dark brown as segments IV, V, and the telson; the rest of the coloring the same as the male.

\section{DESCRIPTION OF THE HOLOTYPE}

CARAPACE. Sub-parallel anterior and posterior margins. The anterior margin with a moderate concavity, forming an obtuse angle. Lateral margins formed by small welldefined granules. Anterior paramedian keel is formed by rounded, spaced, and welldefined granules. Anterior median furrow is wide and flat, with varying sized granules. Marked interocular furrow has no granules. The posterior median furrow is deep with tiny, rounded, and irregularly spaced granules. Posterior marginal furrows are marked, and the median lateral ones are barely visible. There are three pairs of lateral eyes.

Mesosoma. Tergites: corrugated tegument, with well-defined median keel from II to IV. Each tergite has a well-defined posterior keel, with spaced and rounded granules. Tergite VII is pentacarinated. Sternites: moderately granular with elongated stigmata and vestigial median keels. Sternite IV has two paramedian keels formed by a few flattened granules. Sternite V shows two median and two paramedian keels formed by very spaced rounded granules. Sternum is subtriangular. Walking legs have smooth tegument, and segments small keels and spiny spaced granules. 
M. Quiroga et al. THE FIRST REPORT OF TITYUS (SCORPIONES: BUTHIDAE) IN ANZOÁTEGUI STATE, VENEZUELA. A NEW SPECIES. J. Venom. Anim. Toxins incl. Trop. Dis., 2004, 10, 1, p.15.

PeDIPALPS. Femur: pentacarinated. Tibia: with 7 keels. Hand: slightly globous. Oblique lines of denticles on the movable finger (right chela): 14 .

KEELS. Chela. Dorsal: marked with very small granules spaced on the basal two thirds, more evident in the distal third. Dorsal internal: evident, with median granules and rounded in the basal third; in the rest they are flattened and smaller. Digital: flat granules and spaced in the basal third where they are interrupted, although some granules can be seen that continue flattened and closely grouped until the base of the fixed finger. Median external: less evident than the previous keels with flat and spaced granules. They are interrupted at one third of the base of the movable finger. Submedian external: only in the proximal third, marked by rounded granules of median size. Some small ones intercelated. Ventral external: complete with flat and large granules. Ventral internal: slightly marked with small and spaced granules. The general tegument of the chela is subtly coriaceous with granulation (Figures 3, 1a-1b).

Trichobothria. Chela: In the fixed finger two dorsal $(d t, d b)$ and four external trichobotria (eb, esb, est, et). In the hand, two groups of external trichobothria: proximal $\left(E b_{1}, E b_{2}, E b_{3}\right)$ and distal $(E s b, E s t, E t)$. In the ventral side, two trichobothria $\left(V_{1}, V_{2}\right)$ (Figure 3, 1a-1b). Tibia: On the dorsal side they are located: $d_{1}, d_{2}, d_{3}, d_{4}, d_{5}$ and the internal $-i$. In the external side of the tibia, located by areas, there are: $2=e b, 2=e s b$, $1=e m, 1=e t, 1=e s t\left(\right.$ Figure 3, 2a-2b). Femur: five dorsal trichobothria $\left(d_{1}, d_{2}, d_{3}, d_{4}, d_{5}\right)$, four internal $\left(i_{1}, i_{2}, i_{3}, i_{4}\right)$ and two external $\left(e_{1}, e_{2}\right)$ (Figure 3, 3a-3b).

Pecten. Right. Length $3.8 \mathrm{~mm}$. Pectineous teeth (right/left): 15/15.

CAUdal Segments. The dorsal keels of segment I are formed by flattened and slightly lengthened granules. Marked in their distal portion. Interkeel tegument with some delicate granulations. Segment II also has large lengthened and flattened granules that insinuate spiny in the basal half, culminating in a big and conspicuous one at the distal side of the segment. This tendency is maintained in segment III, decreasing in IV. In segment $\mathrm{V}$, they are more spaced and not very marked. The tegument from II to $\mathrm{V}$ segments is coriaceous and smooth (Figure 4a). The ventral keels are double and parallel in their full extension in segment I, consisting of flat, lengthened, and spaced 
granules. Interkeel tegument is coriaceous and smooth. Segment II with double and parallel keels up to two thirds of the segment; they then converge in a single keel and separate again in the base. Segments III and IV are double and parallel at the beginning of the basal third; they then converge in a single keel that divides in the base. Segment $\mathrm{V}$ has a single keel constituted by small and slightly conspicuous granules. Tegument is smooth (Figure 4b). The lateral keels of segment I to IV consist of large and lengthened granules that are progressively interspaced. Segment V does not show any keel, and the tegument is coriaceous and smooth (Figure 5). The telson presents some granulations in the basal region with a furrow slightly marked by a line of small and spaced granules. The sub-aculear tubercle has a marked dorsal promontory formed by three granules; the median being the biggest (Figure 5).

Coloring. Dark brown. Movable and fixed finger, dark brown. Prosoma and metasoma, ochre caudal segment IV is slightly darker than the previous ones. Segment $\mathrm{V}$ and the telson are dark brown (Figure 2a). Holotype measures are shown in Table 1.

\section{DESCRIPTION OF THE PARATYPE (CELT-106)}

HAND. Less globous and shorther than in holotype. Oblique lines of denticles on the movable finger (right chela): 14.

KeELS. Chela. Dorsal: evident in its full extension with rounded and median granules. Dorsal internal: complete with rounded granules slightly separated in the basal third. They become smaller and grouped in the distal third. Digital: in the basal third with granules that are slightly flat, lengthened, and separated. In the middle third, they are spaced and interrupted. Subsequently, they appear more compact up to the base of the fixed finger. Median external: complete with flattened granules, well marked. Submedian external: more marked in the basal third with long and flat granules. Slightly more rounded in the distal third. Ventral external: marked with thick and flat granules. Ventral internal: some flat and dispersed granules in the base; then formed in its full extension by granules, some of median size and some small and rounded (Figure 6, 1a1b). 
M. Quiroga et al. THE FIRST REPORT OF TITYUS (SCORPIONES: BUTHIDAE) IN ANZOÁTEGUI STATE, VENEZUELA. A NEW SPECIES. J. Venom. Anim. Toxins incl. Trop. Dis., 2004, 10, 1, p.17.

Trichobothria. Chela: (Figure 6, 1a-1b). Tibia: (Figure 6, 2a-2b). Femur: (Figure 6, $3 a-3 b)$. The general tegument of the femur and tibia have delicate granulation.

Pecten: Right. Length $3.84 \mathrm{~mm}$. Pectineous teeth (right/left): 16/15.

Caudal Segments. The dorsal keels of segment I are formed by flat, uniform, lengthened granules. The interkeel tegument has small dispersed granules, some grouped as a "v". In segment II, the granules are also lengthened but more separated; they culminate in a conspicuous granule. This progression is repeated in segments III and IV. The interkeel tegument is coriaceous and smooth in segments II to IV. In segment $\mathrm{V}$, the dorsal keels are less evident and the tegument is smooth (Figure 7a). Ventral keels: in segment II, they are double and parallel in the basal half, convergent in the distal third, and separate at the end. In segments III and IV, they are double and parallel in the base, and immediately converge forming a single keel up to the end (Figure $7 \mathrm{~b}$ ). The lateroventral keels are formed by long and flat granules in all segments from I to IV. In segment V, they are more spaced and smaller (Figure 8). The telson, is also coriaceous with some small granules in the basal portion. Subaculear tubercle is large with blunt dorsal granules (Figure 8).

CoLORING. Dark brown. Fixed and movable fingers are dark brown as segments IV, V, and the telson (Figure 2b). The remaining coloring is similar to that of the Holotype.

Tables 1 and 2 show the metric figures of the Type Series.

\section{VARIATION}

The evaluation of species variation was made with specimens of the Morphometric Series (Males, $\mathrm{n}=11$ : CELT-126 to 132: 19/7/1997, CELT-210 to 212: 10/3/1999 and, CELT-225: 5/7/1999) (Females, $\mathrm{n}=31$ : CELT-106 to 125: 19/7/1997, CELT-199 to 209: 10/3/1999) captured in the same locality and by the same collectors of Holotype.

Number of pectineous teeth. Frequency in males $(n=11,20$ pectens, right/left, two broken): 17/16 (1), 16/16 (1), 16/15 (1), 15/16 (1), 15/15 (2), 15/14 (1), 14/15 (1), 14/14 (1), 14/? (1) and, ?/14 (1). Frequency in females $(n=31,60$ pectens, right/left, two 
M. Quiroga et al. THE FIRST REPORT OF TITYUS (SCORPIONES: BUTHIDAE) IN ANZOÁTEGUI STATE, VENEZUELA. A NEW SPECIES. J. Venom. Anim. Toxins incl. Trop. Dis., 2004, 10, 1, p.18.

broken): 17/17 (1), 16/17 (2), 16/16 (2), 16/15 (1), 15/17 (1), 15/16 (4), 15/15 (7), 14/15 (6), 14/14 (4), 12/15 (1) and, ?/15 (2). T. gonzalespongai has a relatively constant number of 15 pectineous teeth, although the male usually has a variable quantity of 1416 , and the female $14-17$.

The number of oblique lines of denticles on the movable finger (right chela). Frequency in males ( $\mathrm{n}=11,10$ movable finger, one broken): 15 (1) and 14 (9). Frequency in females ( $\mathrm{n}=31,31$ movable finger): 15 (1), 14 (25) and, 13 (5).

Table 3 shows the metric figures of the Morphometric Series of T. gonzalespongai (with the medians and 95\% confidence limits). The results demonstrate that the species presents a marked sexual dimorphism (Figure 2) that can be seen in the following structure: 1 . The male is significantly larger than the female (males: $\mathrm{n}=11,77.24 \mathrm{~mm}$ in length [70.71 - 83.33 mm]; females: $\mathrm{n}=31,69.00 \mathrm{~mm}$ in length [67.79-70.07 mm]; $p=0.0163$ ). 2. Length of the carapace, distance between the lateral and median eyes, distance between the median eyes, and the length of the mesosoma are significantly larger in females that in males. 3. Caudal segments $\mathrm{I}$ to $\mathrm{V}$ of the metasoma are significantly longer in males that in females. Caudal segments are significantly wider in females.

\section{DISCUSSION}

Up until now, the distribution of T. gonzalespongai is restricted to the "La Laguna" mountain between 1,600 and 2,200 meters above sea level. It is the first species of this genus that is described for Anzoátegui State. This opens a new ordination for Tityus scorpions in the Venezuelan topography (Figures 9a, 9b), enlarging its distribution in Venezuela; it is the first to be captured in the high mountain area (at 2,130 m above sea level) in the northeastern region of Venezuela.

T. gonzalespongai according to the disposition of the ventral keels of the metasoma belongs to the "androcottoides" group (6), which means that differential diagnosis must 
M. Quiroga et al. THE FIRST REPORT OF TITYUS (SCORPIONES: BUTHIDAE) IN ANZOÁTEGUI STATE, VENEZUELA. A NEW SPECIES. J. Venom. Anim. Toxins incl. Trop. Dis., 2004, 10, 1, p.19.

be established with other species of the northeastern region that form this "artificial group".

The species of the "androcottoides" group geographically closest to T. gonzalespongai are: T. nororientalis (7) typically from Catuaro (Ribero municipality, Sucre State); $T$. monaguensis (6) typically from the cave "Los González" $21 \mathrm{~km}$ from Caripe (Caripe municipality, Monagas State); and T. caripitensis (11) in Caripito (Bolívar municipality, Monagas State).

T. gonzalespongai differs from T. nororientalis (7) in size (T. gonzalespongai: Holotype [CELT-126], male $=77.64 \mathrm{~mm}$; and Paratype [CELT-106], female $=69.90 \mathrm{~mm} . T$. nororientalis: male $=66.96 \mathrm{~mm}$; female $=57.32 \mathrm{~mm}$ ). The pectineous teeth are less numerous in T. gonzalespongai than in T. nororientalis (male and female $=17-20$ ). The most obvious difference is the disposition of the ventral keels of the metasoma. In $T$. nororientalis, segments I and II have two double and parallel ventral keels. In segment III, keels are double in the proximal and median thirds and single in the rest of the segment. In segment IV, keels are double in the proximal third and single in the rest of the segment.

T. gonzalespongai differs from T. monaguensis (6) in size; which also has more pectineous teeth $($ male $=17-21$ and female $=17-20)$.

T. caripitensis $(11)($ male $=91 \mathrm{~mm}$; female $=75 \mathrm{~mm})$ and $T$. surorientalis $(7)($ male $=$ $80.85 \mathrm{~mm})$ are both larger than $T$. gonzalespongai, with more pectineous teeth $(T$. caripitensis: male and female $=19 ;$ T. surorientalis: male $=19-20$, female $=18-19$ ) .

Including $T$. gonzalespongai $\mathrm{n}$. sp. the number of species of the genus reaches 44 species in Venezuela. It also represents the eight largest species in the northeastern region of Venezuela and the six in the "androcottoides" group. This new taxa adds weight to the characterization criteria of the scorpion endemic macroregion in Anzoátegui, Monagas, and Sucre States in the northeast of the country (2-4) and contributes to the lethality map for Venezuelan Tityus species proposed by Borges (1). 
M. Quiroga et al. THE FIRST REPORT OF TITYUS (SCORPIONES: BUTHIDAE) IN ANZOÁTEGUI STATE, VENEZUELA. A NEW SPECIES. J. Venom. Anim. Toxins incl. Trop. Dis., 2004, 10, 1, p.20.

Table 1. Type series: Morphometric data in millimeters of Tityus gonzalespongai $\mathrm{n}$. sp Holotype and male Paratype.

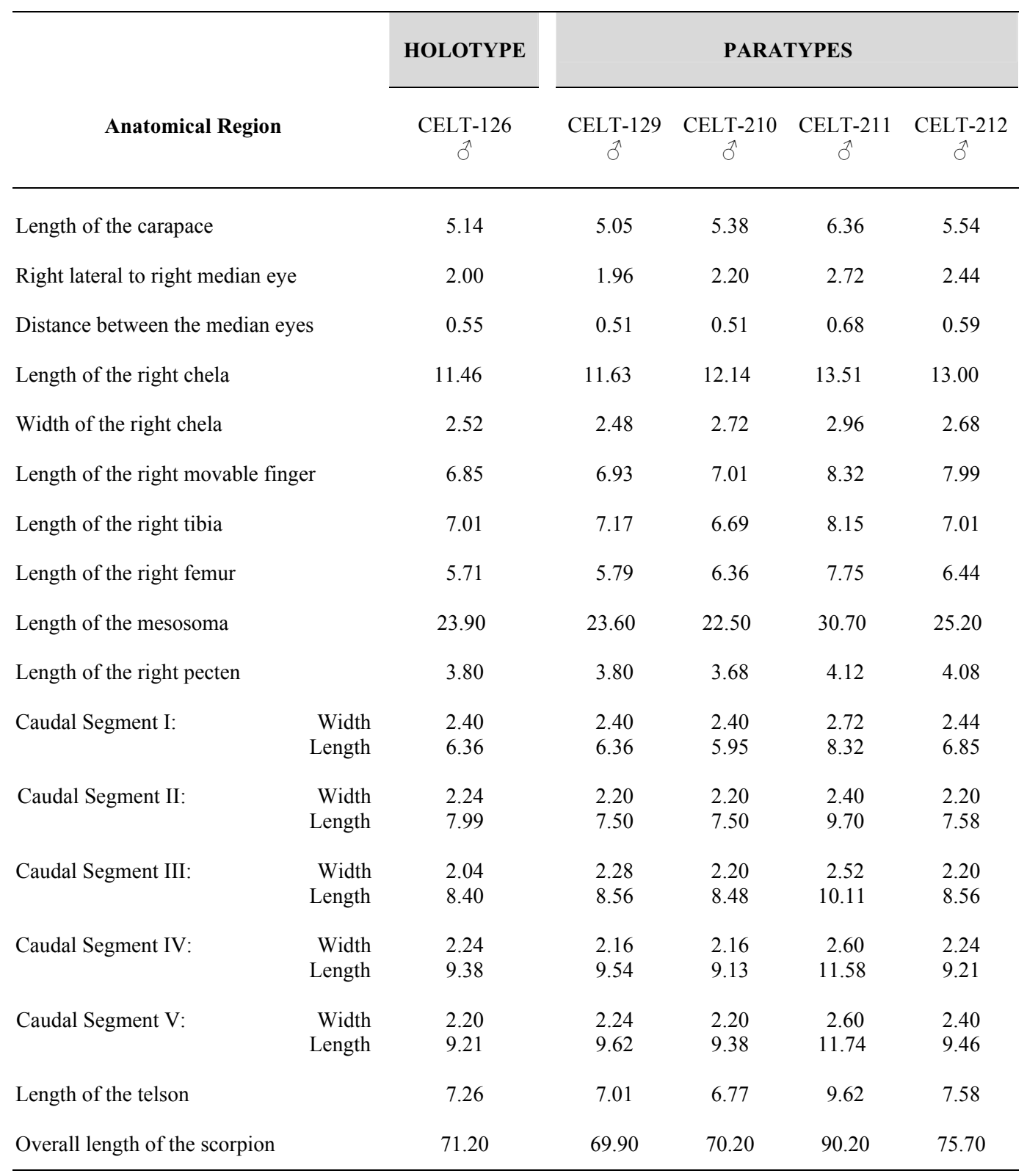


M. Quiroga et al. THE FIRST REPORT OF TITYUS (SCORPIONES: BUTHIDAE) IN ANZOÁTEGUI STATE, VENEZUELA. A NEW SPECIES. J. Venom. Anim. Toxins incl. Trop. Dis., 2004, 10, 1, p.21.

Table 2. Type series: Morphometric data in millimeters of Tityus gonzalespongai $\mathrm{n}$. $\mathrm{sp}$ female Paratypes

\begin{tabular}{|c|c|c|c|c|c|c|}
\hline \multirow[b]{2}{*}{ Anatomical Region } & & \multicolumn{5}{|c|}{ PARATYPES } \\
\hline & & 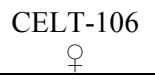 & $\begin{array}{c}\text { CELT-112 } \\
\text { q } \\
\end{array}$ & $\begin{array}{c}\text { CELT-113 } \\
q \\
\end{array}$ & $\begin{array}{c}\text { CELT-115 } \\
q \\
q\end{array}$ & $\begin{array}{c}\text { CELT-117 } \\
q \\
\end{array}$ \\
\hline Length of the carapace & & 5.63 & 5.54 & 5.79 & 5.71 & 5.79 \\
\hline Right lateral to right median eye & & 2.40 & 2.36 & 2.36 & 2.40 & 2.64 \\
\hline Distance between the median eyes & & 0.60 & 0.66 & 0.60 & 0.62 & 0.66 \\
\hline Length of the right chela & & 11.80 & 11.63 & 12.31 & 11.63 & 12.14 \\
\hline Width of the right chela & & 2.52 & 2.40 & 2.64 & 2.64 & 2.64 \\
\hline Length of the right movable finger & & 7.34 & 7.17 & 7.52 & 6.85 & 7.52 \\
\hline Length of the right tibia & & 6.60 & 6.36 & 6.69 & 6.52 & 6.60 \\
\hline Length of the right femur & & 6.28 & 5.54 & 5.95 & 5.95 & 6.19 \\
\hline Length of the mesosoma & & 27.10 & 25.00 & 27.10 & 24.50 & 26.20 \\
\hline Length of the right pecten & & 3.84 & 3.44 & 4.00 & 3.68 & 4.20 \\
\hline Caudal Segment I: & $\begin{array}{l}\text { Width } \\
\text { Length }\end{array}$ & $\begin{array}{l}2.88 \\
4.65\end{array}$ & $\begin{array}{l}3.00 \\
4.57\end{array}$ & $\begin{array}{l}2.88 \\
4.73\end{array}$ & $\begin{array}{l}3.00 \\
4.65\end{array}$ & $\begin{array}{l}3.12 \\
4.24\end{array}$ \\
\hline Caudal Segment II: & $\begin{array}{l}\text { Width } \\
\text { Length }\end{array}$ & $\begin{array}{l}2.80 \\
5.54\end{array}$ & $\begin{array}{l}2.64 \\
4.65\end{array}$ & $\begin{array}{l}2.84 \\
5.46\end{array}$ & $\begin{array}{l}2.84 \\
5.71\end{array}$ & $\begin{array}{l}3.02 \\
5.95\end{array}$ \\
\hline Caudal Segment III: & $\begin{array}{l}\text { Width } \\
\text { Length }\end{array}$ & $\begin{array}{l}2.64 \\
6.11\end{array}$ & $\begin{array}{l}2.60 \\
6.03\end{array}$ & $\begin{array}{l}2.56 \\
6.11\end{array}$ & $\begin{array}{l}2.88 \\
6.36\end{array}$ & $\begin{array}{l}3.12 \\
6.52\end{array}$ \\
\hline Caudal Segment IV: & $\begin{array}{l}\text { Width } \\
\text { Length }\end{array}$ & $\begin{array}{l}2.64 \\
6.93\end{array}$ & $\begin{array}{l}2.56 \\
6.69\end{array}$ & $\begin{array}{l}2.80 \\
6.93\end{array}$ & $\begin{array}{l}3.12 \\
6.85\end{array}$ & $\begin{array}{l}3.04 \\
7.01\end{array}$ \\
\hline Caudal Segment V: & $\begin{array}{l}\text { Width } \\
\text { Length }\end{array}$ & $\begin{array}{l}2.72 \\
7.17\end{array}$ & $\begin{array}{l}2.60 \\
9.50\end{array}$ & $\begin{array}{l}2.72 \\
9.42\end{array}$ & $\begin{array}{l}2.72 \\
7.17\end{array}$ & $\begin{array}{l}2.88 \\
7.34\end{array}$ \\
\hline Length of the telson & & 6.77 & 6.11 & 6.69 & 6.52 & 6.60 \\
\hline Overall length of the scorpion & & 59.90 & 60.80 & 63.10 & 60.70 & 64.20 \\
\hline
\end{tabular}


M. Quiroga et al. THE FIRST REPORT OF TITYUS (SCORPIONES: BUTHIDAE) IN ANZOÁTEGUI STATE, VENEZUELA. A NEW SPECIES. J. Venom. Anim. Toxins incl. Trop. Dis., 2004, 10, 1, p.22.

Table 3. Morphometric data: medians and 95\% confidence intervals of male and female specimens of Tityus gonzalespongai $\mathrm{n}$. sp.

\begin{tabular}{|c|c|c|c|c|c|c|}
\hline \multirow{2}{*}{\multicolumn{2}{|c|}{ Anatomical Region }} & \multicolumn{2}{|c|}{$\begin{array}{c}0 \\
n=11\end{array}$} & \multicolumn{2}{|c|}{$\begin{array}{c}\substack{+\mathrm{n}=31} \\
\end{array}$} & \multirow[b]{2}{*}{$\mathrm{p}$} \\
\hline & & $\begin{array}{l}\text { Mean } \\
(\mathrm{mm})\end{array}$ & $\begin{array}{c}\text { Confidence } \\
\text { Intervals } \\
(95 \%)\end{array}$ & $\begin{array}{l}\text { Mean } \\
(\mathrm{mm})\end{array}$ & $\begin{array}{l}\text { Confidence } \\
\text { Intervals } \\
(95 \%)\end{array}$ & \\
\hline Length of the carapace & & 5.30 & {$[4.97 ; 5.63]$} & 5.71 & {$[5.63 ; 5.75]$} & 0.044475 \\
\hline Right lateral to right median eye & & 2.14 & {$[1.94 ; 2.30]$} & 2.44 & {$[2.38 ; 2.50]$} & 0.004394 \\
\hline Distance between the median eyes & & 0.58 & {$[0.53 ; 0.62]$} & 0.65 & {$[0.64 ; 0.67]$} & 0.003862 \\
\hline Length of the right chela & & 11.80 & {$[10.68 ; 12.66]$} & 11.63 & {$[11.38 ; 11.80]$} & ns \\
\hline Width of the right chela & & 2.60 & {$[2.42 ; 2.82]$} & 2.64 & {$[2.60 ; 2.70]$} & ns \\
\hline Length of the right movable finger & & 6.97 & {$[6.36 ; 7.63]$} & 7.46 & {$[7.34 ; 7.63]$} & ns \\
\hline Length of the right tibia & & 6.93 & {$[6.52 ; 7.50]$} & 6.60 & {$[6.50 ; 6.72]$} & ns \\
\hline Length of the right femur & & 6.45 & {$[5.87 ; 7.06]$} & 5.91 & {$[5.83 ; 6.03]$} & ns \\
\hline Length of the mesosoma & & 23.20 & {$[22.05 ; 24.40]$} & 25.75 & {$[24.95 ; 26.50]$} & 0.00222 \\
\hline Length of the right pecten & & 3.58 & {$[3.36 ; 3.76]$} & 3.62 & {$[3.52 ; 3.72]$} & ns \\
\hline Caudal Segment I: & $\begin{array}{l}\text { Width } \\
\text { Length }\end{array}$ & $\begin{array}{l}2.44 \\
6.28\end{array}$ & $\begin{array}{l}{[2.40 ; 2.60]} \\
{[5.63 ; 6.89]}\end{array}$ & $\begin{array}{l}3.08 \\
4.55\end{array}$ & $\begin{array}{l}{[3.02 ; 3.14]} \\
{[4.40 ; 4.69]}\end{array}$ & $\begin{array}{l}0.000002 \\
0.000021\end{array}$ \\
\hline Caudal Segment II: & $\begin{array}{l}\text { Width } \\
\text { Length }\end{array}$ & $\begin{array}{l}2.40 \\
7.54\end{array}$ & $\begin{array}{l}{[2.28 ; 2.56]} \\
{[6.97 ; 8.60]}\end{array}$ & $\begin{array}{l}2.88 \\
5.71\end{array}$ & $\begin{array}{l}{[2.84 ; 2.94]} \\
{[5.59 ; 5.83]}\end{array}$ & $\begin{array}{l}0.000211 \\
0.000161\end{array}$ \\
\hline Caudal Segment III: & $\begin{array}{l}\text { Width } \\
\text { Length }\end{array}$ & $\begin{array}{l}2.30 \\
8.48\end{array}$ & $\begin{array}{l}{[2.20 ; 2.50]} \\
{[7.96 ; 9.34]}\end{array}$ & $\begin{array}{l}2.78 \\
6.28\end{array}$ & $\begin{array}{l}{[2.72 ; 2.84]} \\
{[6.16 ; 6.40]}\end{array}$ & $\begin{array}{c}0.00043 \\
0.000072\end{array}$ \\
\hline Caudal Segment IV: & $\begin{array}{l}\text { Width } \\
\text { Length }\end{array}$ & $\begin{array}{l}2.23 \\
9.26\end{array}$ & $\begin{array}{c}{[2.16 ; 2.42]} \\
{[8.55 ; 10.26]}\end{array}$ & $\begin{array}{l}2.76 \\
6.93\end{array}$ & $\begin{array}{l}{[2,70 ; 2,86]} \\
{[6,81 ; 7,09]}\end{array}$ & $\begin{array}{l}0.000015 \\
0.000093\end{array}$ \\
\hline Caudal Segment V: & $\begin{array}{l}\text { Width } \\
\text { Length }\end{array}$ & $\begin{array}{l}2.26 \\
9.32\end{array}$ & $\begin{array}{c}{[2.12 ; 2.42]} \\
{[8.63 ; 10.26]}\end{array}$ & $\begin{array}{l}2.78 \\
7.30\end{array}$ & $\begin{array}{l}{[2.72 ; 2.84]} \\
{[7.17 ; 7.42]}\end{array}$ & $\begin{array}{l}0.000047 \\
0.000275\end{array}$ \\
\hline Length of the telson & & 7.14 & {$[6.64 ; 7.91]$} & 6.69 & {$[6.52 ; 6.77]$} & ns \\
\hline Overall length of the scorpion & & 70.20 & {$[63.65 ; 76.75]$} & 62.55 & {$[61,45 ; 63,60]$} & 0,01633 \\
\hline Pectineous teeth (right) & & 15 & {$[14.5 ; 15.5]$} & 15 & {$[14,5 ; 15,0]$} & ns \\
\hline Pectineous teeth (left) & & 15 & {$[14.5 ; 15.5]$} & 15 & {$[15,0 ; 16,0]$} & ns \\
\hline Number of oblique lines of denticles & & 14 & {$[14.00 ; 15.00]$} & 14 & {$[14,00 ; 15,00]$} & ns \\
\hline
\end{tabular}



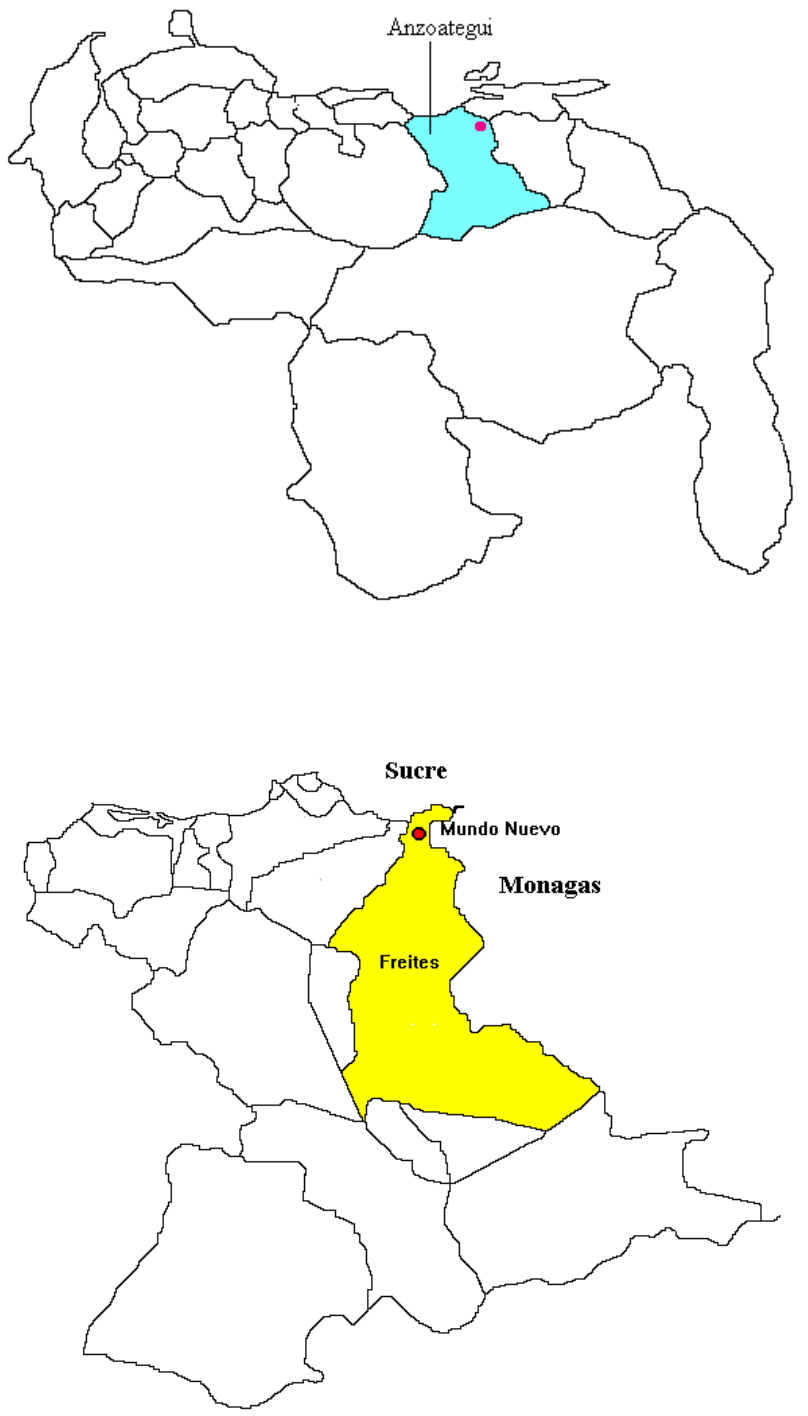

Figure 1. Relative geographical location of Tityus gonzalespongai n. sp. in "La Piedra de Mundo Nuevo" village, Freites municipality, Anzoátegui State (at the border of Monagas and Sucre States), Venezuela. 
M. Quiroga et al. THE FIRST REPORT OF TITYUS (SCORPIONES: BUTHIDAE) IN ANZOÁTEGUI STATE, VENEZUELA. A NEW SPECIES. J. Venom. Anim. Toxins incl. Trop. Dis., 2004, 10, 1, p.24.

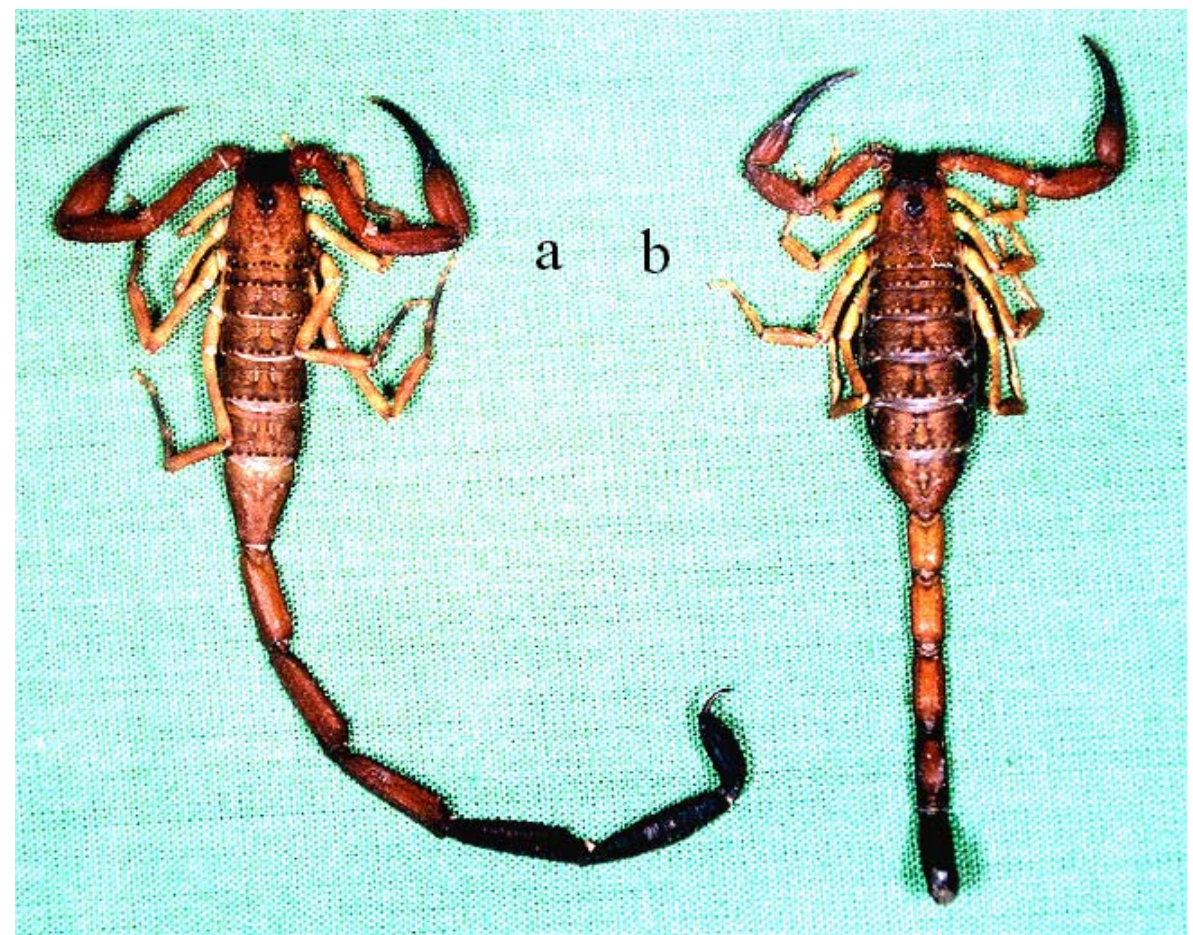

Figure 2. Tityus gonzalespongai n. sp. a. Male (Holotype: CELT-126). b. Female (Paratype: CELT-106). 


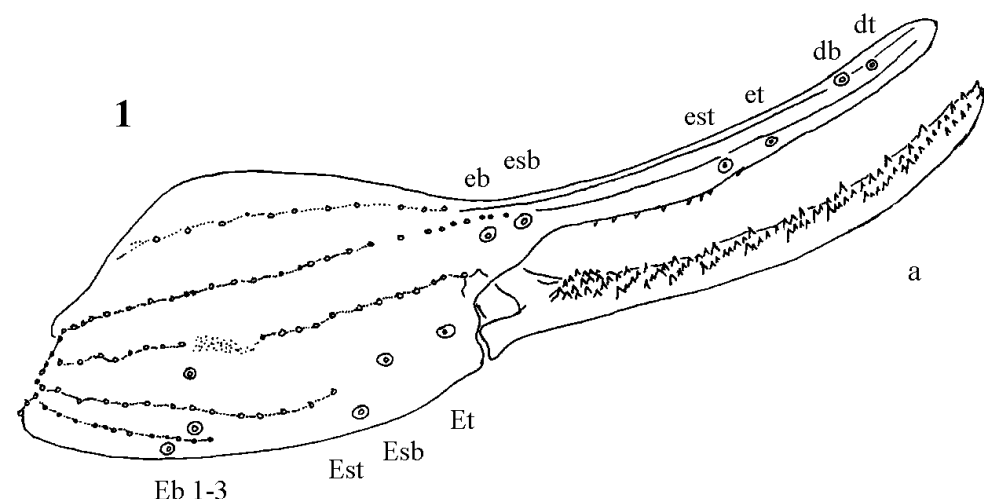

$\mathrm{Eb} 1-3$

b

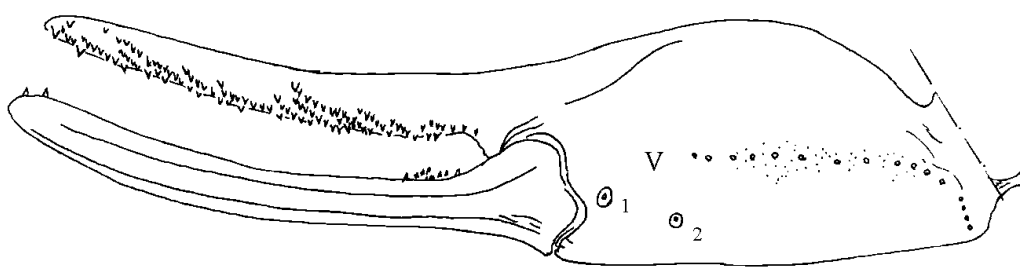

2

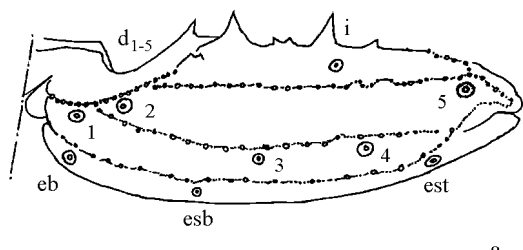

a

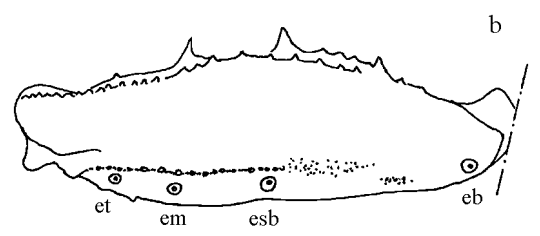

3

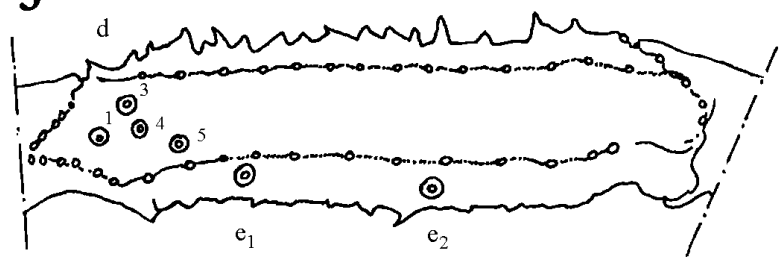

a

b

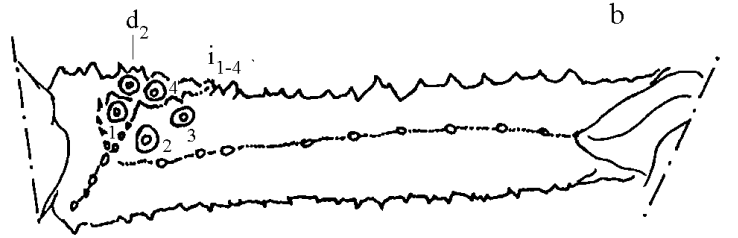

Figure 3. Tityus gonzalespongai $\mathrm{n}$. sp. Male. 1. Right chela. a. Dorsal view. b. Ventral view. 2. Right tibia. a. Dorsal view. b. Ventral view. 3. Right femur. a. Dorsal view. b. Internal view. 
M. Quiroga et al. THE FIRST REPORT OF TITYUS (SCORPIONES: BUTHIDAE) IN ANZOÁTEGUI STATE, VENEZUELA. A NEW SPECIES. J. Venom. Anim. Toxins incl. Trop. Dis., 2004, 10, 1, p.26.

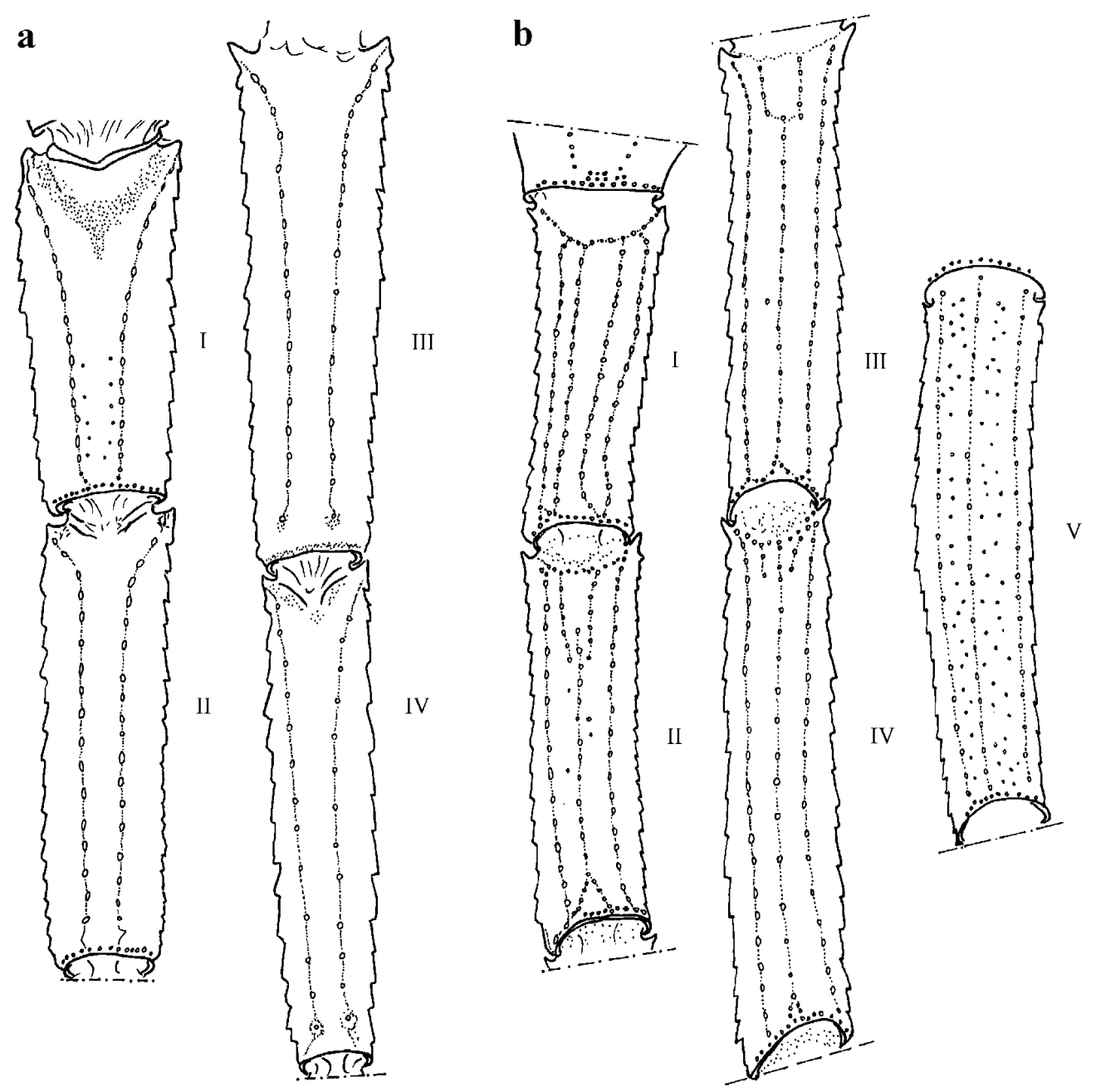

Figure 4. Tityus gonzalespongai n. sp. Male. a. Caudal segments I-IV. Dorsal view. b. Caudal segments I-V. Ventral view. 


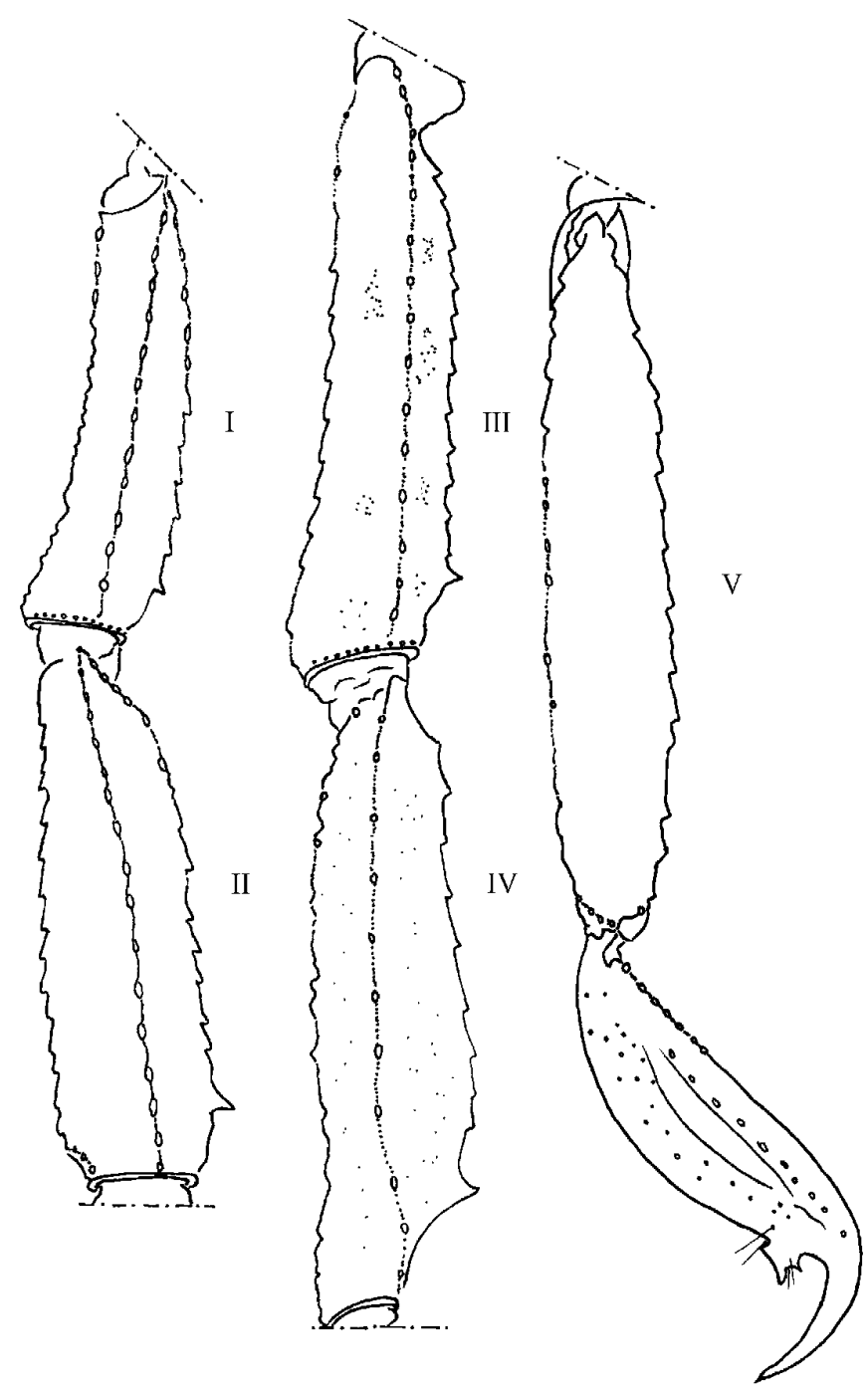

Figure 5. Tityus gonzalespongai n. sp. Male. Caudal segments I-V and telson. Lateral view. 


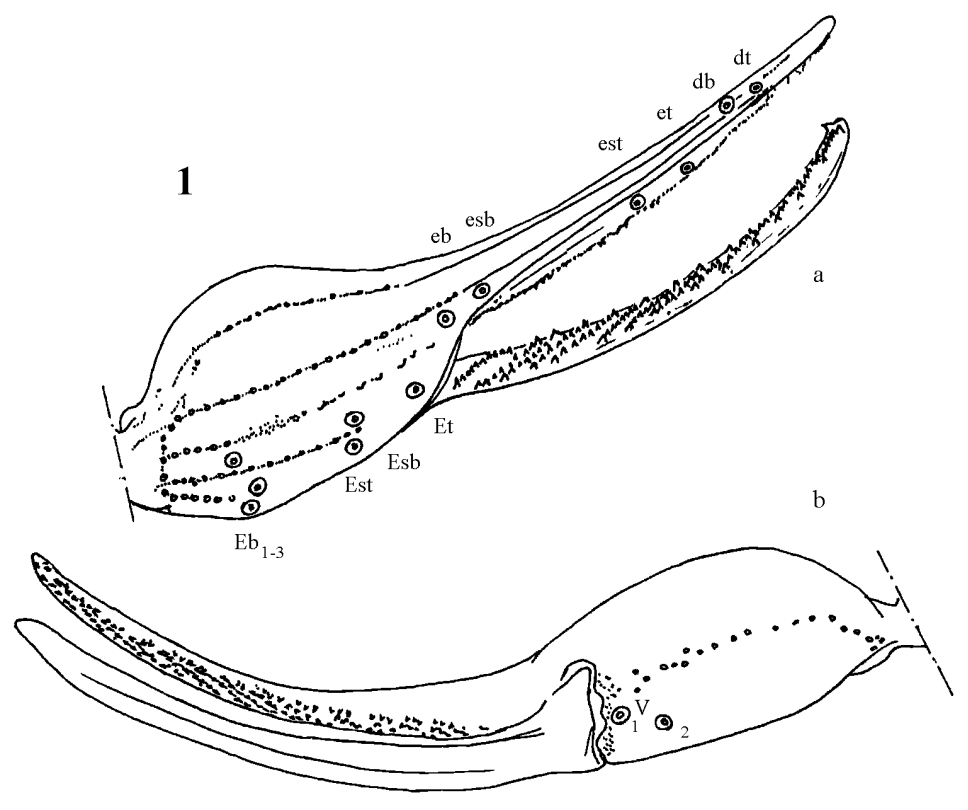

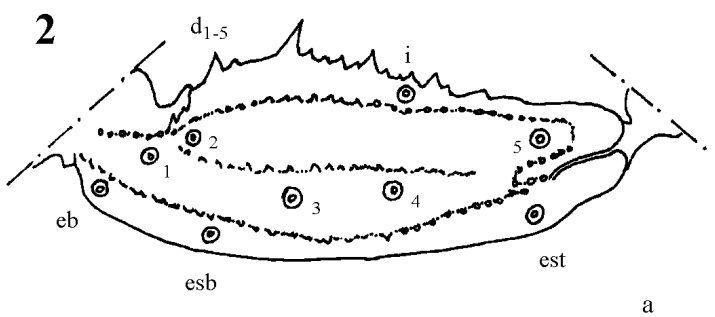

b

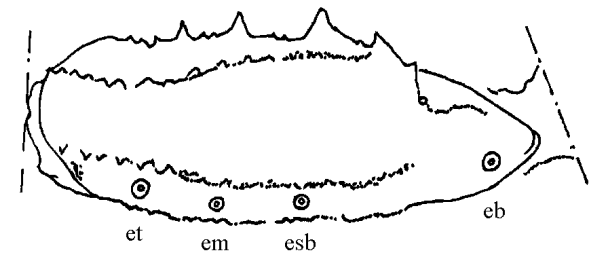

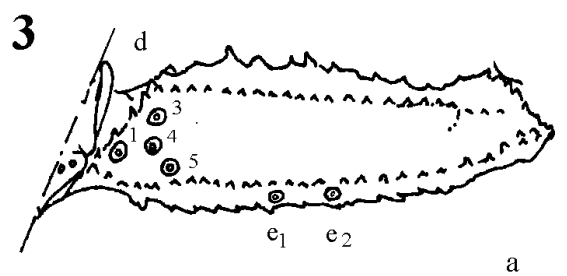

b

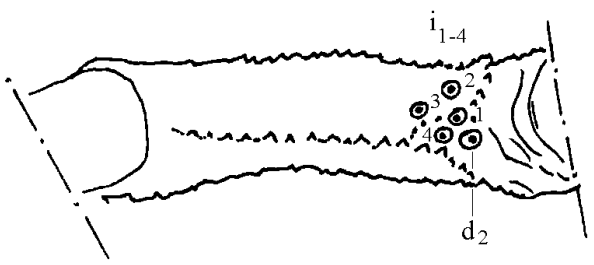

Figure 6. Tityus gonzalespongai n. sp. Female. 1- Right chela. a. Dorsal view. b. Ventral view. 2- Right tibia. a. Dorsal view. b. Ventral view. 3- Right femur. a. Dorsal view. b. Internal view. 
M. Quiroga et al. THE FIRST REPORT OF TITYUS (SCORPIONES: BUTHIDAE) IN ANZOÁTEGUI STATE, VENEZUELA. A NEW SPECIES. J. Venom. Anim. Toxins incl. Trop. Dis., 2004, 10, 1, p.29.

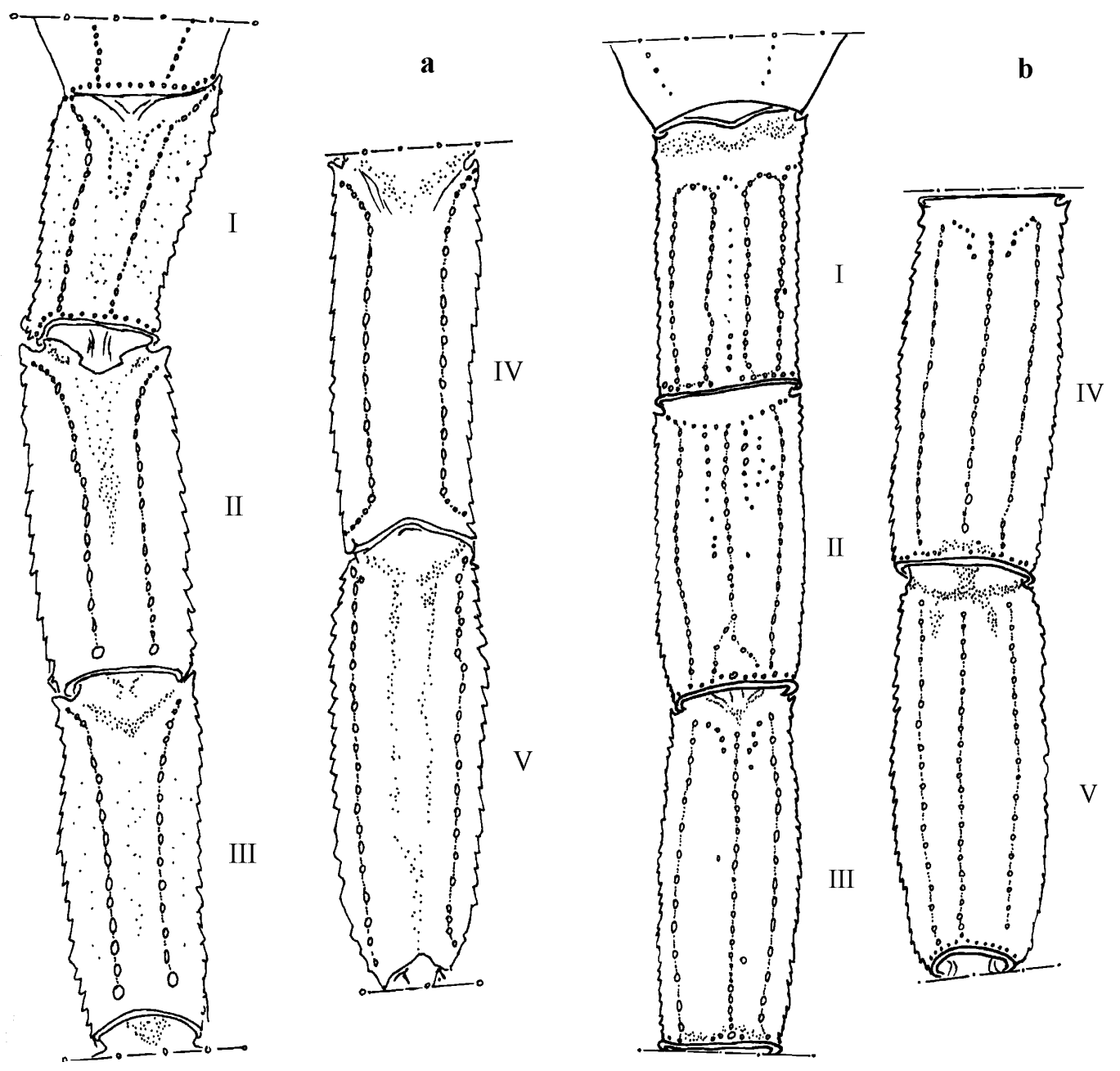

Figure 7. Tityus gonzalespongai n. sp. Female. Caudal segments I-V. a. Dorsal view. b. Ventral view. 


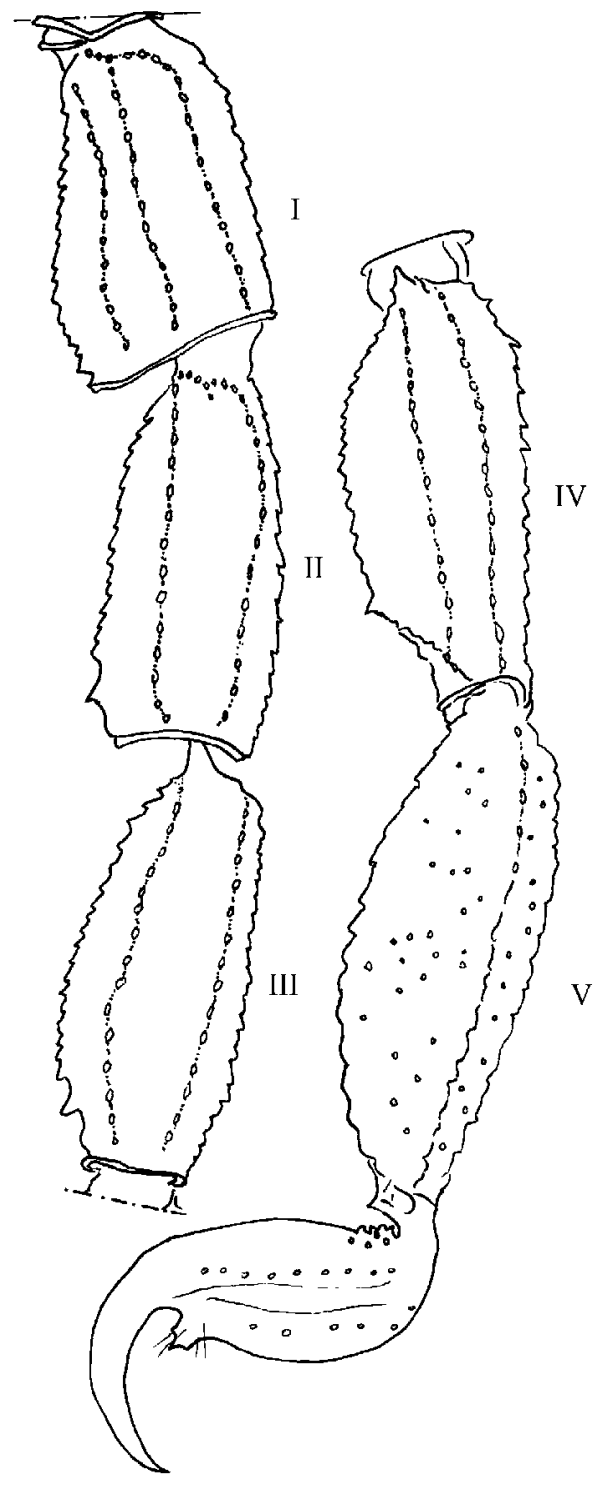

Figure 8. Tityus gonzalespongai n. sp. Female. Caudal segments I-V and telson. Lateral view. 

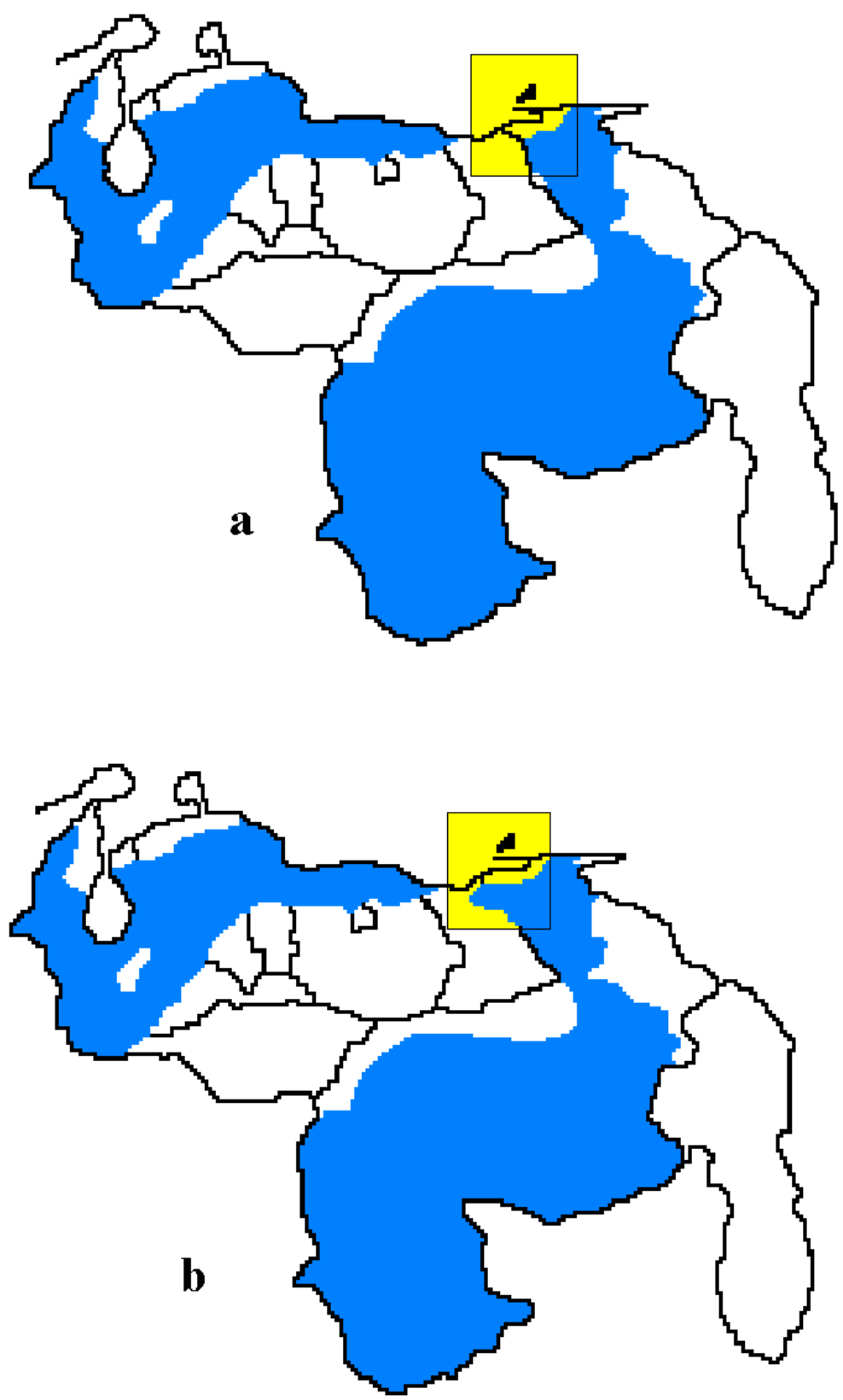

Figure 9. a. Distribution of scorpions of Tityus genus in Venezuela according to González-Sponga (6) and De Sousa et al. (4). b. New distribution for Tityus in Venezuela (including part of the northeast of Anzoátegui State). 
M. Quiroga et al. THE FIRST REPORT OF TITYUS (SCORPIONES: BUTHIDAE) IN ANZOÁTEGUI STATE, VENEZUELA. A NEW SPECIES. J. Venom. Anim. Toxins incl. Trop. Dis., 2004, 10, 1, p.32.

\section{ACKNOWLEDGEMENTS}

Our gratitude to Luis Alberto Rodríguez Maracay, Héctor Romero, Ricardo Marcano, and Dinora Sánchez for their valuable participation in the field expeditions to the "La Laguna" mountain of "Mundo Nuevo" in the Turimiquire sierra of the Anzoátegui State; to the family Romero, owners of "La Orquídea" plantation of the village "La Piedra de Mundo Nuevo", Anzoátegui State, typical locality of Tityus gonzalespongai; to the company TELCOVEN, C.A. and its personnel for the logistical support, especially Mr. Manuel Mouad, Manuel Maita, and Haydee Guerrero; to Professor Victor Castro (INDESA, UDO) for his help in the digitalization of the images; to FUNDACITE-Anzoátegui (PI-015/95, LDS), Consejo de Investigación UDO (CI-10403-0799/97-99, LDS) and FONACIT (F-97001400, CICS) for the financial support; and the CDCH-UCV and the Biological Station "Dr. Alberto Fernández-Yépez" of "Rancho Grande", Agronomy Faculty, UCV, for their excellent logistical support.

\section{REFERENCES}

1 BORGES A. Escorpionismo en Venezuela. Acta Biol. Venez., 1996, 16, 65-75.

2 DE SOUSA L., PARRILLA-ÁLVAREZ P., QUIROGA M. An epidemiological review of scorpion stings in Venezuela. The northeastern region. Review article. J. Venom. Anim. Toxins, 2000, 6, 127-65. (SciELO)

3 DE SOUSA L., KIRIAKOS D., JIMÉNEZ J., MICHIELI D., RODRÍGUEZ C., MIRABAL J., QUIROGA M. Accidente cerebrovascular isquémico por emponzoñamiento escorpiónico: observación clínica. SABER Rev. Cons. Invest. Univ. Oriente, 1995, 7, 7-14.

4 DE SOUSA L., BONOLI S., PARRILLA-ÁLVAREZ P., LEDEZMA E., JORQUERA A., QUIROGA M. The proposal of a new endemic macroregion for

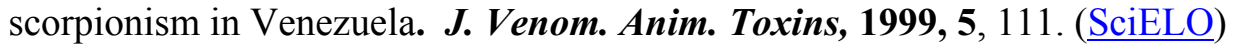

5 EWEL J., MADRIZ A., TOSSI E. Zonas de vida de Venezuela. Caracas: Ministerio de Agricultura y Cría, Dirección de Investigación, 1968. 265p. 
M. Quiroga et al. THE FIRST REPORT OF TITYUS (SCORPIONES: BUTHIDAE) IN ANZOÁTEGUI STATE, VENEZUELA. A NEW SPECIES. J. Venom. Anim. Toxins incl. Trop. Dis., 2004, 10, 1, p.33.

6 GONZÁLEZ-SPONGA MA. Guía para identificar escorpiones de Venezuela. Caracas: Cuadernos Lagoven, 1996a. 204p.

7 GONZÁLEZ-SPONGA MA. Arácnidos de Venezuela: Seis nuevas especies del género Tityus y redescripción de Tityus pococki HIRTS, 1907, Tityus rugosus (SCHENKEL, 1932) n. comb. y Tityus nematochirus MELLO-LEITÃO, 1940 (Scorpionida: Buthidae). Acta Biol. Venez., 1996b, 16, 1-38.

8 GONZÁLEZ-SPONGA MA. Arácnidos de Venezuela: cuatro nuevas especies del género Tityus (Scorpionida: Buthidae). Acta Biol. Venez., 2001, 21, 69-83.

9 GONZÁLEZ-SPONGA MA., D’SUZE G., SEVCIK C. Venezuelan arachnids. Two new species of the Tityus genus (Scorpionida: Buthidae) and the chromatographic profile of venom as a possible taxonomical tool. J. Venom. Anim. Toxins, 2001, 7, 219-39. ( $\underline{\text { SciELO) }}$

10 HUBER O., ALARCON C. Mapa de vegetación de Venezuela. Escala 1:1200000. Caracas: MARNR. Dirección de Cartografía Nacional. 1988.

11 QUIROGA M., DE SOUSA L., PARRILLA-ÁLVAREZ P. The description of Tityus caripitensis. A new Venezuelan scorpion (Scorpionida, Buthidae). $\boldsymbol{J}$.

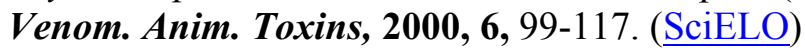

12 STAHNKE HL. Scorpion nomenclature and mensuration. Entomol. News, 1970, 81, 297-316.

13 VACHON M. Êtude des caractères utilisés pour classer les families et les genres de scorpions (Arachnides). 1. La trichobothriotaxie en Arachnologie. Sigles trichobothriaux et types de trichobothriotaxie chez les scorpions. Bull. Mus. Natl. Hist. Nat. Paris, 1973, 104, 857-958. 